\title{
SPECIFIC FEATURES OF LETTERED WORDS' INTEGRATION IN THE GRAPHIC, PHONETIC AND GRAMMATICAL ASPECTS OF THE CHINESE LANGUAGE
}

\author{
Tatiana A. Uryvskaya \\ MGIMO University, Moscow, Russia
}

\begin{abstract}
This paper is devoted to the specific features of lettered words' integration in the graphic, phonetic and grammatical aspects of the Chinese language. The author has analyzed a number of local and foreign studies, covering the main patterns of the lettered words' integration. Based on Liu Yongquan's studies, it was concluded that it's important to strictly follow letters' case. The case difference can distinguish semantics of different lettered words. Native Chinese speakers with high linguistic competence are able to recognize various lettered words in print, but they may not know how to read them out loud. Therefore, the pronunciation of lettered words is associated with a number of issues: the choice of pronunciation standard, the differentiation of initialisms and acronyms, the choice which syllable to stress. Based on the results of previous research, different ways of how borrowed lettered words respond to the grammatical norms of the Chinese language were identified. The empirical analysis was performed with lettered words extracted by the method of continuous sampling from lexicographic sources. Using the cases described in the paper, the author has proved that in addition to such word-formation processes as compounding, semi-affixation, syntactic and morphological transposition, lettered words can also be formed and transformed with morphological contraction.
\end{abstract}

Key words: Chinese, lettered words, abbreviations, initialisms, Chinese hybrid words, assimilations, wordformation.

Citation. Uryvskaya T.A. Specific Features of Lettered Words' Integration in the Graphic, Phonetic and Grammatical Aspects of the Chinese Language. Vestnik Volgogradskogo gosudarstvennogo universiteta. Seriya 2. Yazykoznanie [Science Journal of Volgograd State University. Linguistics], 2021, vol. 20, no. 1, pp. 114-122. DOI: https://doi.org/10.15688/jvolsu2.2021.1.9

УДК $811.581 ’ 373.611$

Дата поступления статьи: 04.06.2020

ББК $81.711-20$

Дата принятия статьи: 02.12.2020

\section{ОСОБЕННОСТИ ИНТЕГРАЦИИ БУКВЕННЫХ СЛОВ В ГРАФИЧЕСКУЮ, ФОНЕТИЧЕСКУЮ И ГРАММАТИЧЕСКУЮ СИСТЕМЫ КИТАЙСКОГО ЯЗЫКА}

\section{Татьяна Александровна Урывская}

Московский государственный институт международных отношений (Университет) МИД России, г. Москва, Россия

\footnotetext{
Аннотация. В статье освещаются особенности интеграции буквенных слов в графическую, фонетическую и грамматическую системы китайского языка. Проанализированы научные труды отечественных и зарубежных лингвистов, исследовавших буквенные слова в китайском языке. С опорой на труды Лю Юнцюаня показано, что при написании буквенных слов китайского языка значимость имеет регистр букв, разграничивающий лексические единицы. Поскольку носители китайского языка с высокой лингвистической компетенцией способны распознавать различные буквенные слова в печати, но могут не знать правил их чтения, в лингвистике обсуждается ряд вопросов, связанных с произношением буквенных слов: выбор произносительной нормы для каждого вида буквенных лексем, дифференциация буквенных аббревиатур и акронимов, постановка ударения. С учетом имеющихся по исследуемой проблематике лингвистических работ определены некоторые особенности подчинения буквенных лексем грамматическим нормам современного китайского языка. Материалом для эмпирического анализа стали буквенные слова, извлеченные
} 
методом сплошной выборки из специализированных лексикографических источников. Установлено, что для создания буквенных слов в китайском языке, наряду со словосложением, полуаффиксацией, синтаксической транспозицией, морфологической транспозицией, применяется и такая словообразовательная модель, как морфемная контракция.

Ключевые слова: китайский язык, буквенные слова, аббревиатура, аббревиатура инициального типа, слово-метис, ассимиляция, словообразование.

Цитирование. Урывская Т. А. Особенности интеграции буквенных слов в графическую, фонетическую и грамматическую системы китайского языка // Вестник Волгоградского государственного университета. Серия 2, Языкознание. - 2021. - Т. 20, № 1. - С. 114-122. - (На англ. яз.). - DOI: https://doi.org/10.15688/ jvolsu2.2021.1.9

\section{Introduction}

According to the definition of the Chinese linguist Liu Yongquan, one of the pioneers in this field of research, the lettered words of the Chinese language (汉语字母词) are “the words whose structure includes Chinese characters and letters of foreign alphabets (mainly Latin letters) or words completely consisting of letters of foreign alphabets. Examples of the first type are B 超, 卡拉 OK; examples of the second type are CD, UFO..." [Liu, 1994, p. 7].

Despite the fact that the full definition of these lexical items was given only in 1994, we can find many facts confirming that the history of their existence in the Chinese language has more than a hundred years. The Chinese researcher Dong Ming in the article "Justifying Chinese Latin Abbreviations” (“汉语字母词存在的合 理性”) cited the fact that X 光线 was included in the "Xin Erya” (“新尔雅”) dictionary in 1903 [Dong, 2014].

Li Xiaohua in her article «Review of the issues related to the inclusion of lettered words in dictionaries》 (“浅议字母词收入辞书问题”) noted an increase of lettered words' usage during The May Fourth Movement. Li Xiaohua, referring to Liu Yonghan, also gives examples of the historical appearance of lettered words in Chinese literature of that period, in particular, 阿 Q from “The True Story of Ah Q" in 1921 “阿 Q 正传” ), N 先生 from “The Story of Hair” 1920 (“头发的故事”) [Li, 2014, p. 46].

\section{Research material and methods}

The material base for the study is specialized dictionaries that give a definition to many lettered words of the Chinese language. With the appearance and wider spread of lettered words in the Chinese language, it became necessary to give an accurate, full definition of the most commonly used lettered items in various fields. In 1996, the $3^{\text {rd }}$ edition of the "Contemporary Chinese Dictionary" (现代汉语词典, hereinafter referred as the CCD) included definitions of 39 lettered words. Inclusion of lettered words in the corresponding section of the $\mathrm{CCD}$ has become systematic and continues to this day. In the $7^{\text {th }}$ edition of the CCD (2016) 235 lettered words were included in the section (CCD, 1996; CCD, 2016). The data from the "Chinese lettered words dictionary" by Liu Yongquan, which contains the most complete and systematized list of lettered words of the contemporary Chinese language also was used as the research material. The main methodology is the continuous sampling method, as well as the method of structural and component analysis of lettered words.

Regular appearance of lettered words in the Chinese press not only confirms the presence of these lexemes in contemporary Chinese, but also indicates the communicative tolerance of Chinese speakers to them [Veselova, Uryvskaya, 2019]. In the author's opinion, the following factors contributed to this communicative tolerance: the need to fill the gaps in the lexical system; the speech efforts saving's principle; psychological factor [Alikberova, Uryvskaya, 2016]. It is worth mentioning that psychological factor is often caused by the desire to give one's speech special novelty and relevance, as well as emphasize the level of education and language competence, which leads to the extensive use of lettered words by Chinese speakers. The desire of native Chinese speakers to transform their speech with foreign inclusions and to impress with their intelligence is common both to an average society member and representatives of the political elite of China. For example, H. Kissinger, an American 
politician, diplomat and expert in the field of international relations, in his book "On China", published for the first time in 2011, wrote about the former General Secretary of the Chinese Communist Party, Jiang Zemin: "He took pride, sometimes exuberantly so, in his talent for foreign languages and knowledge of Western music. With non-Chinese visitors, he regularly incorporated English or Russian or even Romanian expressions into his presentations to emphasize a point...”. In the author's opinion, thereby H. Kissinger indicates loyalty of Jiang Zemin to foreign borrowings [Kissinger, 2015, p. 478].

Based on the data of a sociological survey among native Chinese speakers, which was outlined in the article "Chinese lettered words: barbarism or assimilated borrowing?" in 2019 [Uryvskaya, Veselova, 2019, pp. 431-446], we can draw certain conclusions about high level of communicative tolerance of a part of the Chinese society to these lexical items and effective assimilation of the lettered words in the Chinese language. However, despite the general tolerance, lettered words in the language system sometimes can also cause a negative response. Opponents of lettered words call them an unnatural element imposed by Western culture. According to their opinion, among many attempts to latinize Chinese writing, lettered words have inflicted the most serious damage on the Chinese language [Dong, 2014]. Therefore, we can see a mixed attitude of native Chinese speakers towards this phenomenon, which, however, does not prevent assimilation of these lexical items into the Chinese language system. Further we will evaluate these processes in detail.

\section{Results and discussion}

\section{Specific features \\ of lettered words' integration \\ in the graphic system of the Chinese language}

There are clear rules of writing Chinese characters, which is not the case with the lettered words of the Chinese language. Analyzing the rules of writing lettered words of the Chinese language, Liu Yongquan has identified four categories of lettered words with different features and rules of writing.
The first category includes professional vocabulary and scientific or technical language: IMF - International Monetary Fund, 国际货币 基金组织; CPU - Central Processing Unit, 中 央处理器 [Liu, 2002]. Most of the words in this category are represented by initialisms, and they should be written in uppercase.

The second category includes words that indicate units of measure, for example, $\mathrm{cl}$ 'centiliter', 厘升 or mm - 'millimeter', 毫米 [Liu, 2002]. These words should be written in lowercase.

The third category is represented by words, which can be written both in lowercase and uppercase letters. For example, Internet / internet / INTERNET, 互联网 [Liu, 2002], or SOHO / SoHo - Small office home office, 家庭办公室, 家庭企业 [Liu, 2002]. The choice of lowercase or uppercase letters is insignificant, any of the writing ways will be correct.

The fourth category consists of words containing both lowercase and uppercase letters, for example, IPv4 - Internet Protocol version 4, 互联网的网络通信协议的4号版本 [Liu, 2002] or dBASE-data BASE, 数据库 [Liu, 2002]. The order of lowercase and uppercase letters in the composition of such words is fixed, they have no alternative writings.

In some cases, the choice of uppercase or lowercase letters in lettered words writing determines their semantics. Therefore, when using lettered words, it is necessary to clearly determine which of the four categories a particular lettered word belongs to and what its correct writing should be. In the variety of the Chinese lettered words, we can find following examples: $\mathrm{CD}, \mathrm{Cd}$ and $\mathrm{cd}$ [Liu, 2002], where CD stands for Compact Disc, 光碟; Cd - (from lat.) Cadmium, 镉; and cd 《candela», 坎德拉 is the base unit of luminous intensity.

\section{Specific features of lettered words' integration in the phonetic system of the Chinese language}

Even though lettered words have already become an integral part of the lexical system of the contemporary Chinese language, most of them are represented by borrowings from other languages. Nowadays, the lettered words 
of the Chinese language are increasingly used not only in written, but also in oral speech by native Chinese speakers, so the question of the pronunciation standards for such words arises quite logically. H. Riha, an American researcher of Chinese lettered words, notes that "educated Chinese speakers may recognize a variety of lettered words in print but may not necessarily need to say them aloud and may not know their pronunciation" [Riha, 2010, p. 47]. Lettered words in contemporary Chinese are more often found in print and less often in spoken language, so native Chinese speakers rarely could learn their correct pronunciation by ear. H. Riha also noted the fact that there are no rules for reading lettered words in Chinese specialized dictionaries [Riha, 2010, p. 47].

According to the conclusions made by Liu Yongquan in 2002, reading and pronunciation of lettered words involves the following questions:

A. The choice of pronunciation standard in relation to lettered words. words.

B. Continuous or separate reading of lettered words.

C. Accentuation while reading lettered

With regard to the first question, Liu Yongquan believes that lettered words borrowed from foreign languages are read in accordance with the rules for reading letters of the English alphabet, and not only words from the English language follow this rule [Liu, 2002]. As a part of an experiment in identifying the functioning of lettered words in native Chinese speakers' speech (hereinafter referred to as 'the experiment') described in the $\mathrm{PhD}$ thesis, K.A. Markina distinguishes the following patterns:

A) as lettered words adapt to the basic typological features of the Chinese language, they are read by native Chinese speakers 'by syllables' (especially initialisms).The tendency is based on the fact that the pronunciation of the letters in borrowed initialisms is somewhat similar to the pronunciation of Chinese syllables: $\mathrm{C}$ [si] $=$ 戏 (xì) 'game', D [di] = 地 (dì) 'earth', I [ai ] = 爱 (ài) 'love', $\mathrm{P}$ [pi] = 皮 (pí) 'skin' etc. [Markina, 2008, p. 83];

B) in pronunciation of:

a. Borrowed words in their full spelling (spelled-out words); b. Abbreviations consisting of letters that do not have complete phonological correspondences among Chinese syllables;

c. Abbreviations that do not correspond to the fixed sequence of syllabic elements in Chinese language.

Native Chinese speakers with high linguistic competence tend to get as close as possible to the pronunciation of word elements in accordance with the rules for reading letters of the English alphabet. At the same time, native Chinese speakers with low linguistic competence pronounce them in accordance with pinyin phonetic alphabet pronunciation or with the established pronunciation in Chinese language. In this case "unsystematic distortions of the phonetic appearance of initialisms are observed" [Markina, 2008, p. 84]. H. Riha believes that initialisms are usually spelled by native Chinese speakers, and the letters are pronounced in accordance with the English reading rules. "As pronunciation of many acronyms borrowed from English is based on their English pronunciation, APEC is presumably pronounced as [eip\&k] and IBM as [aibism]. When speakers do not know that a particular acronym is conventionally pronounced as a word in Chinese, they pronounce it as an initialism" [Riha, 2010, p. 47].

Within the framework of this issue, local and foreign researches touch upon the question of pronunciation of Chinese lettered items formed on a basis of pinyin. Liu Yongquan pointed out that there is currently no single rule for reading such abbreviations. Nevertheless, the scholar notices the propensity of Chinese speakers to pronounce them in accordance with the rules for reading English letters [Liu, 2002, pp. 85-90]. However, analysis of the pronunciation variants of such abbreviations provided by K.A. Markina is more detailed:

A) in accordance with Chinese reading of the syllables in the corresponding full words.

$\mathrm{GG}=$ 哥哥 gēge 'elder brother'.

B) in accordance with English names of letters that constitute abbreviation. HSK (汉语水平考试 (Hànyǔ shuǐpíng kăoshì) 'the standardized test of Standard Chinese language') as [eit $\left.\int\right]-[\mathrm{es}]-[\mathrm{kei}]$.

C) multiple variants of pronunciation occur due to inaccurate identification of the source of abbreviation. 
$\mathrm{GB}=$ a) 国标 guóbiāo 'state standard',

b) [d3i bi] - Great Britain.

Regarding the second question, Liu Yongquan expressed an opinion on the existing variability in reading of initialisms. Abbreviations that have vowels in the middle can be taken for a single syllable or as a chain of independent syllables and pronounced as one unit (for example 'SOHO' - 'SO/HO/'). At the same time, abbreviations that do not have a sequential alternation of consonants and vowels (for example, 'MRI', 'GSM') are read letterby-letter according to the patterns discussed before. However, there are abbreviations that have two options of reading - both as a single syllable and as a chain of independent syllables (for example 'ISO' - "ai es əu" and "i: so") [Liu, 2002]. According to the experiment of K.A. Markina, "the overall statistics of reading abbreviations that suggest such dual pronunciation, is approximately at the ratio of 50/50" [Markina, 2008, p. 100].

In relation to the third question on accentuation of lettered words, Liu Yongquan has only pointed out the need for correct accentuation in lettered words to avoid the distortion of their phonetic form. The questions of accentuation in lettered words were out of the scope of K.A. Markina's experiment, but the problem of the presence or absence of tones in the syllables was raised. According to the data, in the process of ascribing tones to the syllables in borrowed lettered words all tones of Chinese language were involved, with the neutral tone being rarely ascribed to syllables in lettered words [Markina, 2008, p. 106]. This is explained by the perception of lettered words (particularly abbreviations) by native speakers as single syllables or chains of independent syllables. While reading lettered words, native speakers naturally ascribe a tone (one of the basic parts of Chinese syllable) to almost all syllables.

The experiment revealed that despite the existing differences in choosing a tone while reading lettered words and abbreviations, the top choice of the respondents is usually the first (flat) tone. In our point of view, the first (flat) tone is distinguished by the special duration and height, which can technically correspond to the stress in the original lettered word. In terms of acoustic characteristics, the syllable with the first tone is closer to the stressed syllables of the borrowed lettered words from the English language, for instance. This may be due to the fact that its duration is similar to such a basic characteristic of the stressed syllable in the English language as duration.

\section{The process of subordination of the borrowed lettered words \\ to the grammar standards of the Chinese language}

As was already noticed, there are several reasons for the emergence and spread of lettered borrowings in the Chinese language: the need to fill the gaps in the lexical system; the speech efforts saving's principle; psychological factor. However, the participation of these lexical units in the word-formation processes of the Chinese language is a solid proof of their transition to the status of 'lettered words of the Chinese language'.

Hybrid words are the products of such wordformation models in the Chinese language as compounding and semi-affixation. The following example illustrates the participation of lettered borrowings in the process of compounding (definitive type):

CIF 价 - CIF jià, CIF - terms of delivery that include Cost, Insurance and Freight, where CIF from the English Cost, Insurance and Freight, and 价 jià - 'price, cost'.

Another example shows the participation of lettered borrowings in semi-affixation process:

IT 化 - IT huà, IT - "process of implementation / transition to information technology', and 化 huà - semi-suffix. This semi - suffix forms a large number of words denoting the process of action, transformation, and transition of an object to another state [Gorelov, 1984, p. 61].

Lettered words usually enter the Chinese language with the original established semantic meaning and belonging to a particular lexical and grammatical category. The transition of original lettered words from one lexical and grammatical category to another is also possible - as a result of the participation of these lexical items in such word-formation processes as syntactic transposition and morphological transposition. According to the definition of V.I. Gorelov, 
syntactic transposition is not accompanied by the change of lexical and morphological environment - the result of this process is only the change of syntactic functions of the original lexical unit [Gorelov, 1984, p. 93]. For example, 吃完饭谁也别走, 咱们卡拉 OK [Liu, 2002]'do not leave after the meal, we will sing karaoke'. 卡拉 OK 'karaoke' is a borrowing from the Japanese language, in which 卡拉 is a phonetic calque from Japanese 'カラ' 'empty' and 'OK' from English 'orchestra' [Liu, 2002]. Initially, 'karaoke' meant sound equipment that allows performing songs to the backing track (Liu, p. 288). However, in the example, the word was syntactically transposed, which determined the transition of the word from the category of nouns to the category of verbs.

Morphological transposition (conversion) implies a change in lexical and morphological environment [Gorelov, 1984, p. 95]. For example, 你的企业 IT 了吗? - 'Has your company applied IT?' [Liu, 2002, pp. 8590]. The term 'IT' belongs to the lexical and grammatical category of nouns, but in the example, it was used as a processual verb. This is evidenced by its position in the sentence and the grammatical indicator $\}$ (located after verbs and some adjectives according to the rules). As a verb, 'IT' acquires the meaning 'the process of implementation and application of Internet technologies'.

In the Chinese language, in view of the morphological and semantic significance of hyphenation, compounding is one of the leading and most effective ways of word formation and word stock replenishment. However, according to I.D. Klenin and V.F. Shchichko, the development of polysyllabic lexical items also gave rise to the opposite tendency of reducing polysyllabic items to a disyllabic standard more often than to a trisyllabic or quadrisyllabic structures [Klenin, Shchichko, 2013, p. 129]. Therefore, the tendency to exceed the standard of dissyllabic form within the framework of the compounding is compensated by such phenomenon as morphemic contraction (which reverts the word to the dissyllabic form). Eventually, due to its effectiveness and active use of its products, this process has become one of the ways of word formation in the Chinese language. According to the definition of V.I. Gorelov, this method is a special kind of abbreviation typical of the Chinese language by its morphological characteristics. It is a process of exclusion of individual morphemes from the composition of a polysyllabic word or phrase.

Previously, this method of formation of new words was applied only to hieroglyphic words of the Chinese language and, according to V.I. Gorelov, was divided into several types:

1. Morphemic contraction of trisyllabic lexical units.

飞机场 (fly - machine - field) $\rightarrow$ 机场 (aerodrome) [Gorelov, 1984, p. 87].

2. Morphemic contraction of quadrisyllabic lexical units.

北京大学 (Beijing University) $\rightarrow$ 北大 [Gorelov, 1984, p. 88].

3. Morphemic contraction of pentasyllabic lexical units.

语言研究所 (speech - language - to investigate - place) $\rightarrow$ 语言所 (institute of linguistics) [Gorelov, 1984, p. 89].

4. Morphemic contraction of a special type.

a) the merging of two words which have a common postpositive morpheme - the formation of one trisyllabic unit. There is a copulative bond between the first morphemes.

明天 (tomorrow) + 后天 (the day after tomorrow) $\rightarrow$ 明后天 (tomorrow or the day after tomorrow) [Gorelov, 1984, p. 90].

b) the merging of several words (usually with an identical morpheme) - the formation of an abbreviated word, including a numeral, which indicates the number of words involved in the contraction process.

农业、农村、农民问题（problems of agriculture, village, and rural population)-三农问题. However, with the emergence and integration of lettered words into the lexical system of the Chinese language, lettered words and their alphabetical components began to follow the rules of morphemic contraction.

Having investigated the dictionary “汉语字 母词词典” written by Liu Yongquan in 2008, we pointed out a number of lettered words, which, in our opinion, are the products of morphemic contraction. They demonstrate the accuracy of the conclusion that there is a process of lettered words' subordination to the grammatical rules of the Chinese language. The lexemes selected may be divided into several groups: 


\section{Group 1:}

a) Truncation of letter component of a hybrid word on a par with truncation of morphemes of postpositive hieroglyphic component:

\begin{tabular}{|l|l|l|l|}
\hline USB 闪盘 & $\rightarrow$ & U 盘 & $\begin{array}{l}\text { USB - flash drive (Liu, } \\
\text { p. 244) }\end{array}$ \\
\hline
\end{tabular}

b) Truncation of letter component of a hybrid word and the use of a monomorphic postpositive hieroglyphic component:

\begin{tabular}{|l|l|l|l|}
\hline GRE 族 & $\rightarrow$ & G 族 & $\begin{array}{l}\text { people taking GRE test to study } \\
\text { abroad (Liu, p. 105) }\end{array}$ \\
\hline
\end{tabular}

\section{Group 2:}

a) The merging of two hybrid words which have a common postpositive morpheme and truncation of the letter components of these words. The component in an abbreviated word is spelled as one letter, which is semantically significant for both original abbreviations:

\begin{tabular}{|l|l|l|l|}
\hline $\begin{array}{l}\text { MBA 族+ } \\
\text { MPA 族 }\end{array}$ & $\rightarrow$ M 族 & $\begin{array}{l}\text { trainees or graduates of the } \\
\text { MBA and MPA programs } \\
\text { (Liu, p. 158) }\end{array}$ \\
\hline
\end{tabular}

b) The merging of two or more hybrid words which have a common postpositive morpheme and truncation of letter components of these words. The component in anabbreviated word is spelled as one letter combination, which is common for all words in contraction process:

\begin{tabular}{|c|c|c|c|}
\hline $\begin{array}{l}\text { What 词 }+ \\
\text { When 词 }+ \\
\text { Where 词 }+ \\
\text { Which 词 }\end{array}$ & $\rightarrow$ & Wh-词 & $\begin{array}{l}\text { Wh-question words of } \\
\text { the English language } \\
\text { (Liu, p. 255) }\end{array}$ \\
\hline
\end{tabular}

\section{Group 3:}

a) Abbreviated hybrid words, which imply a hieroglyphic numeral (the number of combined words), a letter component (common to all words combined), and a hieroglyphic component indicating the meaning of abbreviated hybrid word:

\begin{tabular}{|l|l|l|l|}
\hline $\begin{array}{l}\text { Communication }+ \\
\text { Computer }+ \\
\text { Control + 革命 }\end{array}$ & $\rightarrow$ & $\begin{array}{l}\text { 三 C } \\
\text { 革命 }\end{array}$ & $\begin{array}{l}\text { the implementation } \\
\text { of communication } \\
\text { computerization, } \\
\text { and management } \\
\text { a u t o m a t i o n } \\
\text { processes (Liu, } \\
\text { p. 291) }\end{array}$ \\
\hline
\end{tabular}

b) Abbreviated hybrid words, which imply an Arabic numeral (the number of combined words) a letter component (common to all words combined), and a hieroglyphic component indicating the meaning of abbreviated hybrid word:

\begin{tabular}{|l|l|l|}
\hline $\begin{array}{l}\text { Clean }+ \\
\text { Cycle }+ \\
\text { Control }+ \\
\text { 原则 }\end{array}$ & $\rightarrow$ 3C 原则 & $\begin{array}{l}\text { principles of urban waste } \\
\text { management: prevention } \\
\text { of waste generation, } \\
\text { comprehensive waste } \\
\text { utilization, appropriate } \\
\text { measures in waste } \\
\text { management (Liu, } \\
\text { p. 276) }\end{array}$ \\
\hline
\end{tabular}

c) Abbreviated hybrid words, which imply a hieroglyphic numeral (the number of combined words) and a letter component (common to all combined words):

\begin{tabular}{|l|l|l|l|}
\hline $\begin{array}{l}\text { Technology }+ \\
\text { Trade }+ \\
\text { Tribes }\end{array}$ & $\rightarrow$ & 三T & $\begin{array}{l}\text { technology, trade and the } \\
\text { collectivist spirit (Liu, } \\
\text { p. 292) }\end{array}$ \\
\hline
\end{tabular}

d) Abbreviated hybrid words, which imply an Arabic numeral (the number of combined words) and a letter component (common to all combined words):

\begin{tabular}{|c|c|c|c|}
\hline $\begin{array}{l}\text { Reduce }+ \\
\text { Reuse }+ \\
\text { Recycle }\end{array}$ & $\rightarrow$ & $3 R$ & $\begin{array}{l}\text { modern environmental } \\
\text { requirements (waste- } \\
\text { reduction, renewable energy } \\
\text { sources, and reuse) (Liu, } \\
\text { p. } 278 \text { ) }\end{array}$ \\
\hline
\end{tabular}

e) The merging of two groups of foreign words, distinguished by the principle of having a common letter component. In an abbreviated lettered word, the first hieroglyphic numeral (the number of words combined in the first group) and the letter component (common to all combined words of the first group) are followed by the second hieroglyphic numeral (the number of combined words in the second group) and the letter component (common to all combined words of the second group):

\begin{tabular}{|l|l|l|l|}
\hline $\begin{array}{l}\text { Computer }+ \\
\text { Communication }+ \\
\text { Control; } \\
\text { factory } \\
\text { Automation }+ \\
\text { office } \\
\text { Automation }+ \\
\text { home } \\
\text { Automation }+ \\
\text { agricultural } \\
\text { Automation }\end{array}$ & $\rightarrow$ & $\begin{array}{l}\text { 三C } \\
\text { 四A }\end{array}$ & $\begin{array}{l}\text { computerization, } \\
\text { communication, } \\
\text { control; automation } \\
\text { of ind u s trial } \\
\text { enterprises, office, } \\
\text { household and } \\
\text { agriculture) (Liu, } \\
\text { p. 291) }\end{array}$ \\
\end{tabular}




\section{Conclusion}

Lettered words emerged in Chinese print at the beginning of the $20^{\text {th }}$ century. By the middle of the century, they began to appear in Chinese literature, and due to the new realia of China, beginning with the 1978 political course, they are gaining popularity nowadays.

The article is based on a series of observations on the lettered words' integration into the Chinese language made by the author in the course of analysis of lettered words' dictionaries published in China in the period of 1996-2016.

Firstly, we have analyzed a number of local and foreign researches, covering main issues regarding specific features of various types of lettered words' integration into the phonetic and graphic systems of the Chinese language.

Secondly, the achievements of previous research made it possible to identify the peculiarities of subordination of borrowed lettered words to the grammatical standards of the Chinese language. The cases described in this paper prove that, in addition to such word-formation processes as compounding, semi-affixation, syntactic and morphological transposition, lettered words are also subject to morphological contraction. In our opinion, the expansion of the range of lettered words' grammatical functions indicates a high degree of assimilation of these lexical items into the Chinese language.

The Chinese language is a communication instrument of citizens of the state that occupies an increasingly prominent place in political and economic arenas of the world. The investigation of the main vectors of intralingual changes in the contemporary Chinese language and their motives are relevant areas of research. Nowadays, the leadership of PRC shows commitment to preserving and maintaining Chinese identity and traditions. The Chinese language and Chinese characters are a huge layer of a unique culture. The emergence, distribution and assimilation of lettered words certainly have direct impact on the traditions of this language, to a certain extent determining the ways of its development. In this regard, we believe that the status of Chinese lettered words, the legitimacy of their usage, as well as the rules regulating their writing, reading, and grammatical functions are relevant discussion topics in Chinese philology.

\section{REFERENCES}

Alikberova A.R., Uryvskaya T.A., 2016. Modern Trends in Chinese Language: Integration of Letter Words into the Language System. Uchenye Zapiski Kazanskogo Universiteta. Seriia «Gumanitarnye nauki», vol. 158, no. 6, pp. 1592-1600.

Gorelov V.I., 1984. Leksikologiya kitayskogo yazyka [Chinese Language Lexicology]. Moscow, Prosveshchenie Publ. 216 p.

Khamatova A.A., 2012. Trends of the Development of the Chinese Vocabulary in the Beginning of the XXI Century. Vestnik Irkutskogo gosudarstvennogo lingvisticheskogo universiteta, no. 4 (21), pp. 9-13.

Kissinger H., 2015. O Kitaye [On China]. Moscow, AST Publ. 635 p.

Klenin I.D., Shchichko V.F., 2013. Leksikologiya kitayskogo yazyka [Chinese Language Lexicology]. Moscow, Vostochnaya kniga Publ. 273 p.

Markina K.A., 2008. Novye tendencii v razvitii kitajskoj leksiki: bukvennye slova kitajskogo jazyka kak projavlenie ego integracii s jelementami inoj tipologii: diss. cand. phylol. nauk [New Tendencies in the Development of Modern Chinese Words: Chinese Littered Words as the Manifestation of Its Integration with Its Integration with the Elements of the Different Typology. Cand. philol. sci. diss.]. Moscow. $180 \mathrm{p}$.

Riha H., 2010. Lettered Words in Chinese: Roman Letters as Morpheme-Syllables. Working Papers in Linguistics, no. 59, pp. 44-51.

Uryvskaya T.A., Veselova L.S., 2019. Chinese Lettered Words: Barbarism or Assimilated Borrowing? Vestnik of Saint Petersburg University. Asian and African Studies, vol. 11, iss. 4, pp. 431-446. DOI: $10.21638 /$ spbu13.2019.402.

Veselova L.S., Uryvskaya T.A., 2019. About Communicative Tolerance of Chinese Speakers to Lettered Words. Sbornik statey $i$ dokladov uchastnikov XII Mezhdunarodnoy nauchnoprakticheskoy konferentsii «Rossiya Kitay: istoriya i kultura» [Proceedings of the $12^{\text {th }}$ International Conference "Russia - China: History and Culture"]. Kazan, «Fen» AN RT Publ. pp. 103-107.

Dong Ming, 2014. Hanyu zimuci cunzaide helixing [Justifying Chinese Latin Abbreviations]. Journal of Zhejiang Gongshang University, vol. 125, no. 2, pp. 45-52. (In Chinese).

Li Xiaohua, 2014. Qianyi zimuci shouru cishu wenti [Review of the Issues Related to the Inclusion of Lettered Words in Dictionaries]. Modern Chinese, no.6, pp. 46-48. (In Chinese). 
Liu Yongquan, 1994. Tantan zimuci [Talk About Lettered Words]. Language Planning, no. 10, pp. 7-9. (In Chinese).

Liu Yongquan, 2002. Guanyu hanyu zimucide wenti [The Issue of Lettered Words in Chinese]. Applied linguistics, no. 1, pp. 85-90. (In Chinese).

Tang Jingqiong, 2013. Zimuci ru "Xiandai hanyu cidian" [Lettered Words Enter the Contemporary Chinese Dictionary]. Journal of Suzhou University of Science and Technology (Social Science), vol. 31, no. 2, pp. 104-108. (In Chinese).

\section{DICTIONARIES}

Liu - Liu Yongquan. Hanyu zimuci cidian [Chinese Lettered Words Dictionary]. [S. 1.], Foreign Language Teaching and Research Press, 2008. 332 p. (In Chinese).

CCD, 1996 - Contemporary Chinese Dictionary. $3^{\text {rd }}$ ed. Beijing, The Commercial Press, 1996. 1832 p. (In Chinese).

$C C D, 2016$ - Contemporary Chinese Dictionary. $7^{\text {rd }}$ ed. Beijing, The Commercial Press, 2016. 1799 p. (In Chinese).

\section{Information About the Author}

Tatiana A. Uryvskaya, Candidate for a Degree, Lecturer, Department of Chinese, Vietnamese, Thai and Laotian Languages, MGIMO University, Prosp. Vernadskogo, 76, 119454 Moscow, Russia, uryvski@yahoo.com, https://orcid.org/0000-0002-0146-1365

\section{Информация об авторе}

Татьяна Александровна Урывская, соискатель ученой степени кандидата наук, преподаватель кафедры китайского, вьетнамского, тайского и лаосского языков, Московский государственный институт международных отношений (Университет) МИД России, просп. Вернадского, 76, 119454 г. Москва, Россия, uryvski@yahoo.com, https://orcid.org/0000-0002-0146-1365 